University for Business and Technology in Kosovo

UBT Knowledge Center

Nov 2nd, 9:00 AM - Nov 3rd, 5:00 PM

\title{
Quality Management in Public Sector; How is the QM approach employed in the Public Administration of the Republic of Kosovo?
}

Shkelzen Sopjani

Follow this and additional works at: https://knowledgecenter.ubt-uni.net/conference

Part of the Business Commons

\section{Recommended Citation}

Sopjani, Shkelzen, "Quality Management in Public Sector; How is the QM approach employed in the Public Administration of the Republic of Kosovo?" (2012). UBT International Conference. 61.

https://knowledgecenter.ubt-uni.net/conference/2012/all-events/61

This Event is brought to you for free and open access by the Publication and Journals at UBT Knowledge Center. It has been accepted for inclusion in UBT International Conference by an authorized administrator of UBT Knowledge Center. For more information, please contact knowledge.center@ubt-uni.net. 


\title{
Quality Management in Public Sector How is the QM approach employed in the Public Administration of the Republic of Kosovo?
}

\author{
Ph.D. Can. Shkelzen Sopjani ${ }^{1}$
}

ABSTRACT. Quality Management as approach started to be rapidly developed and gained use in the early 1950's in Japan, while the result produced in Japan made the US organizations to embrace this approach and develop it further by introducing the 'new' approach called Total Quality Management.

Quality Management produced enormous results in the private sector; however, number of authors questioned the suitability of the Quality Management approach in the Public Sector ${ }^{l}$. Despite the hesitation expressed, many others see a little problem in adopting this approach in the government sector.

Government of Kosovo made its priority the reform of Public Administration. In this regard, numbers of laws and other documents were amended; however, so far these did not produce any significant results in the improvement of services produced by the government officials. Having in mind that the core to the introduction of the Total Quality Management in any organization is a need to be acutely sensitive to the cultural aspects of the organization ${ }^{l}$ as well as the fact that human factor is very important piece in relation to Quality Management approach, considering that researches show that people related issues (resistance to change, lack of ownership, fear and the suspicion of motives of management, etc.) represent the most of difficulties ${ }^{146}$, this paper will show how is Quality Management Approach is addressed in the laws, strategies and other documents produced by the Republic of Kosovo as well as how do they impact the reform of Public Administration.

Keywords: Quality, Management, Public, Administration, Reform.

\footnotetext{
146 The MIBTEL index is a general basket which includes all the shares listed on the Stock Exchange and has been active since January 3, 1994. It's a value weighted index that is calculated every minute during the continuous trading phase on the basis of prices. It is preferred to use this index, representative of all securities listed on the Italian stock market, because it is larger and closer to the "market portfolio". It is important to note, finally, that in calculating the returns, all the adjustments (dividends, stock splits, etc.) have been taken into account. Hence the prices for both the securities and the basket are "Official Price" and "Price Index", respectively, and were taken, as mentioned above, from Datastream. Currently it is no longer active as it has been replaced by the FTSE Italy All-Share.
} 